\title{
MANAGEMENT AND AWARENESS ON HEALTH HAZARDS OF HOUSEHOLD WASTE: A COMMUNITY BASED STUDY
}

Naresh Manandhar ${ }^{*}$, Syed Ataullah'², Rishav Raj ${ }^{2}$, Pallabi Chakraborty², Supriya Raya Adhikari², Deeksha Sharma ${ }^{2}$

\begin{abstract}
Affiliation
1. Associate Professor, Department of Community Medicine, Kathmandu Medical College, Nepal

2. MBBSStudent, Kathmandu Medical College, Nepal
\end{abstract}

\section{ARTICLE INFO}

Received : 12 October, 2020

Accepted : 22 August, 2021

Published : 04 November, 2021

(C) Authors retain copyright and grant the journal right of first publication with the work simultaneously licensed under Creative Commons Attribution License CC - BY 4.0 that allows others to share the work with an acknowledgment of the work's authorship and initial publication in this journal.

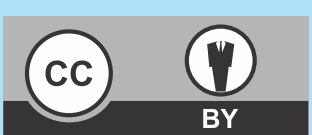

ORA 247

DOI: https://doi.org/10.3126/bjhs.v6i2.40307

* Corresponding Author

Dr. Naresh Manandhar

Associate Professor

Department of Community Medicine

Kathmandu Medical College, Nepal

Email:nareshsayami@yahoo.com

ORCID: https://orcid.org/0000-0002-4113-7076

\section{Citation}

Naresh Manandhar, Syed Ataullah, Rishav Raj, Pallabi Chakraborty, Supriya Raya Adhikari, Deeksha Sharma. Management and awareness on health hazards of household waste: A Community based study. BJHS 2021;6(2)15. 1440-1443.

\section{ABSTRACT}

\section{Introduction}

Waste is physical things or unwanted materials that are of no use to the human beings. ${ }^{1}$ Waste management is the activities and actions required to manage waste from its inception to its final disposal.

\section{Objectives}

The objective of study is to assess the management and awareness on health hazards of household waste in a community of Khopasi, Kavrepalanchowk district.

\section{Methodology}

The study design was descriptive cross-sectional and it was conducted from $10^{\text {th }}$ November to $15^{\text {th }}$ November 2019 at Khopasi, Kavrepalanchowk using convenience sampling technique in 281 households. The statistical package for social sciences (SPSS) version 20 was used for data entry and analysis. Descriptive statistics like frequency, mean, percentage etc was calculated.

\section{Result}

The mean age of 281 respondents was 44.89 years. Similarly $43.8 \%$ of respondents considered waste management as a major issue and $84.3 \%$ had knowledge about health hazards due to improper waste disposal. Forty-seven percentages of the respondents disposed of their waste through waste collecting vehicle, $26 \%$ by burning, $17 \%$ threw their waste by riverbank, and $9 \%$ threw their waste indiscriminately in the surrounding area.

\section{Conclusion}

The majority of respondents were aware about adverse effect on their health due to improper waste disposal. However the knowledge of waste management program is poor. They throw waste in the river bank or indiscriminately in open places.

\section{KEY WORDS}

Disposal, environment, solid waste, waste management 


\section{INTRODUCTION}

Waste is physical things or unwanted materials that are of no use to the human beings. ${ }^{1}$ Waste management is the activities and actions required to manage waste from its inception to its final disposal. The process of waste managements are the collection, transport, treatment and disposal of waste, together with monitoring and regulation. ${ }^{2}$ Waste can be solid, liquid, or gaseous and each type has different methods of disposal and management. Waste management includes all types of waste like industrial, biological and household waste. Waste management is aimed to reduce adverse effects of waste on human health, the environment or aesthetics. ${ }^{3}$

Waste management usually done by the techniques of Landfills, Incineration, Recycling, Biological Reprocessing, Waste Collection and Energy Recovery. The first principle of waste management is waste hierarchy, which follows the "Three R rule" for waste prevention and minimization being the most desirable goal. The three $\mathrm{R}$ stands for Reduce, Reuse and Recycle. The second principle is the extended producer responsibility, adding all the environmental costs to the market price of a product, which includes end-of-life disposal. In addition the third principle is the polluter or a waste generator pays for the appropriate disposal of the waste. $^{4}$

Each type of waste management corresponds to a management process. Pre-sorting is required for properly management of the waste. The sorting includes the separation of recyclable waste from non-recyclable waste, and then energy recovery. Hence, there is a huge economic potential that needs to be leveraged by public and private sector. ${ }^{4}$

Solid waste management is one of the major environmental issues in urban areas of many developing countries, including Nepal. Urban population growth and economic development lead to increasing generation of municipal solid waste. The Government of Nepal enacted the Solid Waste Management Act of 2011 to maintain a clean and healthy environment by minimizing the adverse effects of solid waste on public health and the environment. ${ }^{3}$ The local bodies have been made responsible for the construction, operation, and management of infrastructure for collection, treatment, and final disposal of solid waste. Aim of the study was to assess management and awareness on health hazards of household waste in a community of Khopasi, Kavrepalanchowk district.

\section{METHODOLOGY}

Descriptive cross-sectional study was conducted from $10^{\text {th }}$ November to $15^{\text {th }}$ November 2019 at Khopasi, Kavrepalanchowk. The sample size (n) was calculated usingthe prevalence of household waste management and awareness proportion $50 \%$.

$\mathrm{n}=\mathrm{Z}^{2} \mathrm{pq} / \mathrm{e}^{2}$

Where,

$Z=1.96$ is the score at $95 \%$ confidence interval $p$ is the estimated prevalence, which we have taken as $50 \%$ $q=100 \%-p=50 \%$

e is the estimated error (6\%).

$\mathrm{n}=(1.96)^{2} *(0.5 * 0.5) /(0.06)^{2}$

$=267$

Assuming that there will be $5 \%$ non-response rate therefore the final sample size was 281 . The convenience sampling technique was used to select 281 households and interview was conducted to the household head. A pretested questionnaire was used for the data collection by face-toface interviews. Ethical approval was taken from Institutional Review Committee of Kathmandu Medical College and written consent was taken from the respondents after explaining the purpose of study. The identity of the respondents and their responses were kept confidential and the data was used for the research purpose only. The statistical package for social sciences (SPSS) version 20 was used for data entry and analysis. Descriptive statistics like frequency, mean, percentage etc was calculated.

\section{RESULTS}

The mean age of all 281 respondents was 44.89 years with the standard deviation of 14.89 years. The mean age for male was 46.29 years, and the figure was 43.61 years for female with the standard deviation of 14.79 years and 14.35 years for male and female respectively.

\begin{tabular}{|c|c|c|}
\hline \multicolumn{2}{|c|}{ Characteristics } & \multirow{2}{*}{$\begin{array}{r}\text { No. of respondents } n(\%) \\
49(17.4)\end{array}$} \\
\hline \multirow{4}{*}{$\begin{array}{l}\text { Age Group } \\
\text { (in Years) }\end{array}$} & $15-29$ & \\
\hline & $30-44$ & $100(35.6)$ \\
\hline & $45-59$ & $93(33.1)$ \\
\hline & $\geq 60$ & 39(13.9) \\
\hline \multirow{2}{*}{ Sex } & Male & $134(47.7)$ \\
\hline & Female & $147(52.3)$ \\
\hline \multirow{3}{*}{ Religion } & Hindu & $233(82.9)$ \\
\hline & Buddhist & $47(16.7)$ \\
\hline & Muslim & $1(0.4)$ \\
\hline \multirow{4}{*}{ Ethnic group } & Brahmin & $73(26.0)$ \\
\hline & Chhetri & $64(22.8)$ \\
\hline & Janjati & $142(50.5)$ \\
\hline & Other & $2(0.7)$ \\
\hline \multirow{5}{*}{$\begin{array}{l}\text { Education } \\
\text { status }\end{array}$} & No education & $31(11.0)$ \\
\hline & Primary & $13(4.6)$ \\
\hline & Secondary & 49 (17.4) \\
\hline & $\begin{array}{l}\text { Intermediate / } \\
(10+2)\end{array}$ & $85(30.2)$ \\
\hline & $\begin{array}{l}\text { Bachelor and } \\
\text { above }\end{array}$ & $103(36.7)$ \\
\hline \multirow{4}{*}{ Occupation } & Agricultural & $155(55.2)$ \\
\hline & Service & $21(7.5)$ \\
\hline & Business & $57(20.3)$ \\
\hline & House maker & $48(17.0)$ \\
\hline
\end{tabular}

It was observed that the highest percentage 100 (35.6\%) of the respondents were from the age group $30-44$ years and followed by $45-59$ years and that was 93 (33.1\%). Females $(52.3 \%)$ were more than males $(47.7 \%)$ in the study population. The majority of the respondents were from Hindu 233(82.91\%) religion followed by Buddhist 47 (16.7\%) 
and Muslim $1(0.4 \%)$. The ethnical distribution of the total respondents showed 73 (26\%) were Brahmin, 93 (33.1\%) Janjati, 64 (22.8\%), Chhetri and 49 (17.4\%) were belong to others ethnic group. In the education status of respondents, $31(11.0 \%)$ received no formal education, $13(4.6 \%)$ had completed their primary level of education, 40 (14.2\%) had completed their secondary level of education, 85 (30.2\%) had completed their intermediate level of schooling,103 (36.7\%) had pursued bachelor degree. In the occupation of respondents. Majority were belong to agricultural155 $(55.2 \%), 57(20.3 \%)$ were in business, $48(17.0 \%)$ were house maker and the least $21(7.5 \%)$ were in service. (Table 1 )

\begin{tabular}{|c|c|c|}
\hline Knowledge & Yes (\%) & No (\%) \\
\hline Waste management is a major issue & $123(43.8)$ & $158(56.2)$ \\
\hline Waste Management Program & $25(9.9)$ & $256(91.1$ \\
\hline Health Hazards Due to Improper Waste Disposal & $237(84.3)$ & $44(15.7)$ \\
\hline
\end{tabular}

According to the research findings, 123 (43.8\%)of the respondents were considered waste management as a major issue in their locality while the rest of respondents 158 (56.2\%) did not considered waste management as a important issue. Only 25 (9.9\%)of the respondents were aware of waste management program running in their locality. The majority of the respondents 256 (91.1\%) did not know about the waste management programs in their area. Among the total respondents, $237(84.3 \%)$ had knowledge about health hazards due to improper waste disposal 44 (15.7\%) did not have knowledge about health hazards due to improper waste disposal.

\begin{tabular}{|c|c|c|}
\hline & Characteristics & $\begin{array}{c}\text { No. of } \\
\text { household }\end{array}$ \\
\hline \multirow{5}{*}{$\begin{array}{l}\text { Collection of } \\
\text { Household Waste }\end{array}$} & Dustbin & $113(40.2)$ \\
\hline & Plastic Bags & $82(29.2)$ \\
\hline & Direct disposal & $51(18.1)$ \\
\hline & Card board box & $31(11.0)$ \\
\hline & Others & $6(2.1)$ \\
\hline \multirow{5}{*}{$\begin{array}{l}\text { Mode of household } \\
\text { waste disposal }\end{array}$} & Municipal waste collecting vehicle & $133(47.3)$ \\
\hline & Burning & $74(26.3)$ \\
\hline & Threw waste by river bank & $48(17.1)$ \\
\hline & Threw waste indiscriminately & 26(9.3) \\
\hline & Public bins & $3(1.0)$ \\
\hline \multirow{2}{*}{ Separate waste } & Yes & $155(55.2)$ \\
\hline & No & $126(44.8)$ \\
\hline
\end{tabular}

Among the 281 respondents, 113 (40.2\%)used to collect their waste in dustbin, $82(29.2 \%)$ in plastic bags, and 51 (18.1\%) had no specific method of collection, 31 (11.0\%) in cardboard boxes and remaining $6(2.1 \%)$ used other methods such as burning. One hundred and thirty three (47.3\%)of the respondents disposed of their waste through waste collecting vehicle, 74 (26.3\%) by burning, 48 (17.1\%) threw their waste by river bank, 26 (9.3\%) threw their waste indiscriminately in the surrounding area and only $1.0 \%$ used public bins. Among the respondents, only $55.2 \%$ separated their waste while the remaining $44.8 \%$ did not separate their waste. (Table 3)

Among the 281 respondents, only $43 \%$ were satisfied with their waste collecting service and the rest $57 \%$ thought the waste collecting service could be much more efficient.

\section{DISCUSSION}

A study conducted in municipalities of Nepal revealed that an average household generates 170 grams/capita/day ${ }^{1}$. Households in Terai municipalities generate nearly $80 \%$ more waste than those in mountain region municipalities. The analysis of household waste composition indicated that the highest waste category was organic waste with $66 \%$, followed by plastics with $12 \%$, and paper and paper products with $9 \% .{ }^{3}$ Unhealthy disposal of solid waste is considered as one of the most important problems in many societies. The problem of waste management has arisen recently in developing countries where there is little history of the implementation of formal and informal community environmental education awareness program. ${ }^{5}$

Management of solid waste is a growing concern in Nepal as urban population densities increase and flat usable land is in short supply. Although small urban centers were declared municipalities, they suffer from a lack of infrastructural, technical and financial resources to tackle the problems of waste management. ${ }^{3}$ This study will assess the management and disposal of the household wastes of Khopasi village.

The mean age of 281 respondents was 44.89 years and maximum of respondents belonged to age group 30-34 years. In present research $44.5 \%$ of respondents considered waste management is a major issue in their locality which is consistent with the findings of Azuike where it was $50.7 \%{ }^{6}$

The knowledge of waste management is poor $(9.9 \%)$ in the present study respondents which very low with compared to the findings of Arora where it was $46 \% .{ }^{5}$ In the mode of household waste disposal, the present study revealed that $26.3 \%$ of respondents were disposed by burning. Similar finding was found in the study conducted in Lahore, Pakistan $(24 \%)^{7}$ and Mangalore, India (30\%). ${ }^{8}$ The practice of burning of waste is common because this is a rural area in a developing country where modern household waste management systems are not available.

Around $26 \%$ of respondents used to throw waste in the riverbank or indiscriminately in open places in present study which is less than the finding of Azuike ${ }^{6}$ and Shahzadi ${ }^{7}$ where it was $48.5 \%$ and $42 \%$ respectively. This difference may due to different time improving in awareness and education status. Majority of the respondents (84.3\%) were aware about adverse effect on their health due to improper waste disposal, which is consistent with the finding of Shahzadi ${ }^{7}$ where it was $72 \%$. The present study found that around $40 \%$ of the respondents collected their waste in dustbin. This is consistent with the finding of Shahzadi ${ }^{7}$ where it was $41 \%$.

Only about $42.3 \%$ were satisfied with the current waste management. Many who were not satisfied thought that the frequency of waste collection done by the municipality could be increased. People also required a proper drainage system for their disposal of the waste water. They also though public bins at frequent interval present throughout the locality could be efficient in managing waste in the 
community. The present research revealed that only $55.2 \%$ practiced presorting of waste before disposal where as it was $17.3 \%$ in the study conducted by Yoada. ${ }^{9}$ This difference may due to different study sites and time period. The presorting of household waste yields the separation of recyclable waste from non-recyclable waste, and subsequently the energy recovery. Therefore, presorting has a tremendous economic potential that needs to be practice and take advantages by public and private sectors. Presorting creates jobs, which improved waste management leads to a better quality of life for local populations, by improving hygiene conditions and reducing health risks related to illegal dumping and inadequate garbage collection. The main advantage of the sustainable waste management is to lessen the impact on the environment, by improving air and water quality and contributing to the reduction of greenhouse gas emissions.

\section{CONCLUSION}

The present study indicates that majority of respondents were aware about the adverse effect on their health due to improper waste disposal. However the knowledge of waste management is poor. They throw waste in the riverbank or indiscriminately in the open places. They were not satisfied with the current waste management program. Hence, the municipalities should try to reach every sector of the community to collect the waste or at least provide public bins at frequent interval throughout the locality. There should be the arrangement of health education programs in the community for educating people about the proper disposal methods. Programs should be focused on preventive measures that can be taken to prevent diseases due to accumulation of house hold waste.

\section{LIMITATIONS OF THE STUDY}

The study could not cover a large area, was conducted in 6 days and thus comprehensive data collection was not possible due to time constraint. The participants less than 18 years were not included in the study. The many participants were not willing to give information regarding their view on the waste management and the method of waste disposal.

\section{ACKNOWLEDGEMENT}

Authors express deepest gratitude to Professor Dr. Dr. Sunil Kumar Joshi, Head of Department of Community Medicine, Kathmandu Medical College for providing continuous guidance and support. Authors also thank to all the respondents for providing valuable information.

\section{CONFLICT OF INTEREST}

None

\section{FINANCIAL DISCLOSURE}

None

\section{REFERENCES}

1. Kiran KG, Kini S, Ravi K, Santhosh NP,Kiran NU. KAP study of solid waste disposal of households in Kuttar \& Manjanadi Panchayath covered under gramaskhema programme of K.S. Hegde Medical Academy, NUJHS Vol. 5, No.3, September 2015, ISSN 2249-7110

2. United Nations Statistics Division - Environment Statistics. Retrieved on 6 January, 2019.Available from: http://www.unstats.un.org.

3. Solid Waste Management in Nepal, Current Status and Policy Recommendations. Asian Development Bank, 2013, Mandaluyong City, Philippines.

4. Solar impulse foundation: Waste management solutions, how to shape the future of waste? Retrieved on Feb20, 2019.Available from https://solarimpulse.com/waste-management-solutions

5. Arora L, Agarwal S. Knowledge, Attitude and Practices regarding Waste Management in Selected Hostel Students of University of Rajasthan, Jaipur, International Journal of Chemical, Environmental and Pharmaceutical Research Pharmaceutical Research. JanuaryApril, 2011; 2(1): 40-3

6. Azuike EC, Nwabueze SA, Onyemachi PE, Egenti BN, Okafor KC,
Aniemena RC et al. Household Waste Management; Voices of Residents of Anaocha Local Government Area of Anambra State, Nigeria, Journal of Environmental Protection, 2015, 6, 1394-401. Available from: http://www.scirp.org/journal/jep http://dx.doi.org/ 10.4236/jep.2015.612121

7. ShahzadiA, Hussain M, Afzal M, Gillani SA. Determination the Level of Knowledge, Attitude, and Practices Regarding Household Waste Disposal among People in Rural Community of Lahore, Int. J. Soc. Sc. Manage. 2018;5(3): 219-24. DOI: 10.3126/ijssm.v5i3.20614

8. Kumar M, Nandini N. Community attitude, perception and willingness towards solid waste management in Bangalore city, Karnataka, India, International journal of environmental sciences.2013;4(1). doi: 10.6088/ijes.2013040100009

9. YoadaRM ,Chirawurah D, Adongo PB. Domestic waste disposal practice and perceptions of private sector waste management in urban Accra, BMC Public Health 2014; 14:697. http://www. biomedcentral.com/1471-2458/14/697 